\title{
Formation of niobium oxide and carbide nanofibers from poly(vinyl alcohol)/niobium oxide composite nanofibers
}

\author{
Koji Nakane $\cdot$ Michiko Morinaga $\cdot$ Nobuo Ogata
}

Received: 6 May 2013/Accepted: 19 July 2013/Published online: 1 August 2013

(c) The Author(s) 2013. This article is published with open access at Springerlink.com

\begin{abstract}
Poly(vinyl alcohol)-niobium oxide $\left(\mathrm{Nb}_{2} \mathrm{O}_{5}\right)$ composite nanofibers (precursors) were formed by electrospinning employing water as a solvent for the spinning solution. The precursors were converted into $\mathrm{Nb}_{2} \mathrm{O}_{5}$ or carbide $(\mathrm{NbC})$ nanofibers by heating them in air or Ar. Hexagonal $\mathrm{Nb}_{2} \mathrm{O}_{5}$ nanofibers with high-specific surface area were obtained by heat-treatment of the precursors in air. NbC nanofibers could be obtained below theoretical temperatures calculated from thermodynamics data, indicating that the precursor is a nano-scale mixture of $\mathrm{Nb}$ and carbon sources.
\end{abstract}

\section{Introduction}

Many kinds of inorganic nanofibers have been obtained by heat-treatment of organic-inorganic composite precursor nanofibers formed by electrospinning (ES) [1,2]. Almost all of the inorganic nanofibers obtained from the precursors are metal oxide nanofibers [3-6], but the reports of metal carbide or nitride nanofibers have increased gradually in recent years [7-10].

We focused on the formation of niobium oxide $\left(\mathrm{Nb}_{2} \mathrm{O}_{5}\right)$ and niobium carbide $(\mathrm{NbC})$ nanofibers. $\mathrm{Nb}_{2} \mathrm{O}_{5}$ is widely used in catalysts, oxygen sensors, electrochromic devices, optical filters, and so on [11]. There are some reports about the formation of $\mathrm{Nb}_{2} \mathrm{O}_{5}$ nanofibers from organic-inorganic composite precursor nanofibers obtained by ES. Poly(vinyl acetate) $/ \mathrm{Nb}_{2} \mathrm{O}_{5}$ (obtained by sol-gel reaction of niobium ethoxide) [12] and poly(vinyl pyrrolidone) (PVP)/niobium

K. Nakane $(\bowtie) \cdot$ M. Morinaga $\cdot$ N. Ogata

Department of Materials Science and Engineering, University

of Fukui, Bunkyo 3-9-1, Fukui 910-8507, Japan

e-mail: nakane@matse.u-fukui.ac.jp ethoxide composites were used as the precursors to form the $\mathrm{Nb}_{2} \mathrm{O}_{5}$ nanofibers $[13,14]$. These precursors were prepared by using organic solvents (ethanol or acetone) as the spinning solutions. On the other hand, $\mathrm{NbC}$ is used as structural materials resistant to high temperatures (the melting point of $\mathrm{NbC}$ is $3600{ }^{\circ} \mathrm{C}$ [15]) and corrosive atmospheres, abrasives, superconductors, and high-performance permanent magnets. NbC nanowire arrays have been synthesized via biotemplate method [16]. The nanowires have a length of $1-50 \mu \mathrm{m}$ and a diameter of $30-100 \mathrm{~nm}$. The growth of the nanowire arrays attributed to a vapor-liquid-solid growth mechanism. However, the formation of $\mathrm{NbC}$ nanofibers using $\mathrm{ES}$ has not been reported. If the $\mathrm{NbC}$ nanofibers can be developed, they would be applied as a super-refractory filter and a constructional material for nuclear facilities as alternate materials for commercially available $\mathrm{SiC}$ fibers $(\mathrm{SiC}$ is a low activation material).

In this study, we formed poly(vinyl alcohol) (PVA)/ $\mathrm{Nb}_{2} \mathrm{O}_{5}$ particle composite nanofibers by ES using water as a solvent of the spinning solution and used the nanofibers as a new precursor to form $\mathrm{Nb}_{2} \mathrm{O}_{5}$ and $\mathrm{NbC}$ nanofibers. The structure of the nanofibers obtained was also investigated.

\section{Experimental}

Materials

Poly(vinyl alcohol) (PVA; degree of polymerization: 1500) was obtained from Wako Pure Chemicals Ind., Ltd., Japan. $\mathrm{Nb}_{2} \mathrm{O}_{5}$ sol was a kind gift from Taki Chemical Co., Ltd., Japan (Nb-G6000, content: $\mathrm{Nb}_{2} \mathrm{O}_{5} 6 \%, \mathrm{NH}_{4} \mathrm{OH}$, under $1 \%$, dispersed particle size: ca. $15 \mathrm{~nm}$, disperse media: water). 
Formation of PVA/ $\mathrm{Nb}_{2} \mathrm{O}_{5}$ composite nanofibers (precursors) by ES

PVA (14 wt \%) aqueous solution was prepared. $\mathrm{Nb}_{2} \mathrm{O}_{5}$ sol was added to the PVA solution to produce transparent $\mathrm{PVA} / \mathrm{Nb}_{2} \mathrm{O}_{5}$ mixed solution (spinning solution).

The mixed solution was loaded into a plastic syringe $(2 \mathrm{ml})$ equipped with a needle (needle diameter: $0.7 \mathrm{~mm}$ ). The solution extrusion rate was $0.5 \mathrm{ml} / \mathrm{h}$. A voltage of $17 \mathrm{kV}$ was applied to the needle, and the PVA/ $\mathrm{Nb}_{2} \mathrm{O}_{5}$ (70/ $30 \mathrm{wt} \%)$ composite nanofibers were then deposited on a collector at a room temperature $\left(23.5^{\circ} \mathrm{C}\right)$. The collector (copper plate) was grounded, and the distance between the tip of the needle and the collector was $15 \mathrm{~cm}$. The nanofibers obtained were used as a precursor to form $\mathrm{Nb}_{2} \mathrm{O}_{5}$ and $\mathrm{NbC}$ nanofibers.

Formation of $\mathrm{Nb}_{2} \mathrm{O}_{5}$ and $\mathrm{NbC}$ nanofibers by heat-treatment of the precursors

The PVA $/ \mathrm{Nb}_{2} \mathrm{O}_{5}$ composite nanofibers were heated to a given temperature in an alumina tube furnace (Asahi Rika Seisakusyo Co., Ltd., AHRF-30KC-9P, Japan) at $500-1500{ }^{\circ} \mathrm{C}$ for $3 \mathrm{~h}$ in air or Ar gas flow, and $\mathrm{Nb}_{2} \mathrm{O}_{5}$ or $\mathrm{NbC}$ nanofibers were obtained. The flow rate of Ar gas was $3.5 \mathrm{l} / \mathrm{min}$.

\section{Apparatus and procedure}

The structure of the nanofibers was observed with a scanning electron microscope (SEM) (Keyence VE-9800, Japan) and transmission electron microscope (TEM) (JEOL JEM-2100, Japan). Using a digitizer on the enlarged SEM images, the fiber diameter and its standard deviations at each nanofiber were estimated. X-ray diffraction (XRD) measurement was taken using $\mathrm{CuK}_{\alpha}$ with a $\mathrm{Ni}$ filter (30 kV, $15 \mathrm{~mA}$ ) (Rigaku MiniFlex II, Japan). Nitrogen adsorption isotherms $\left(-196^{\circ} \mathrm{C}\right)$ of the nanofibers were measured with Micromeritics TriStar 3000, USA.

\section{Results and discussion}

Formation of $\mathrm{Nb}_{2} \mathrm{O}_{5}$ nanofibers by heat-treatment of PVA/ $/ \mathrm{Nb}_{2} \mathrm{O}_{5}$ composite nanofibers

Many beads (size: ca. $1 \mu \mathrm{m}$ ) were observed in the nanofibers when the spinning solutions with greater than $\mathrm{Nb}_{2} \mathrm{O}_{5}$ $40 \mathrm{wt} \%$ were used. Thus, the $\mathrm{PVA} / \mathrm{Nb}_{2} \mathrm{O}_{5}$ composite nanofibers $\left(\mathrm{PVA} / \mathrm{Nb}_{2} \mathrm{O}_{5}=70 / 30 \mathrm{wt} \%\right)$ were selected as the precursor to obtain well-formed inorganic nanofibers (The viscosity of the spinning solution is $242 \mathrm{mPa}$ at $23.5^{\circ} \mathrm{C}$ ). Figure $1 \mathrm{a}, \mathrm{b}$ shows SEM and TEM images of the
$\mathrm{PVA} / \mathrm{Nb}_{2} \mathrm{O}_{5}$ (70/30 wt\%) composite nanofibers (precursors) obtained by ES. The average fiber diameter of the nanofibers is ca. $170 \mathrm{~nm}$. From Fig. 1b, we found that the
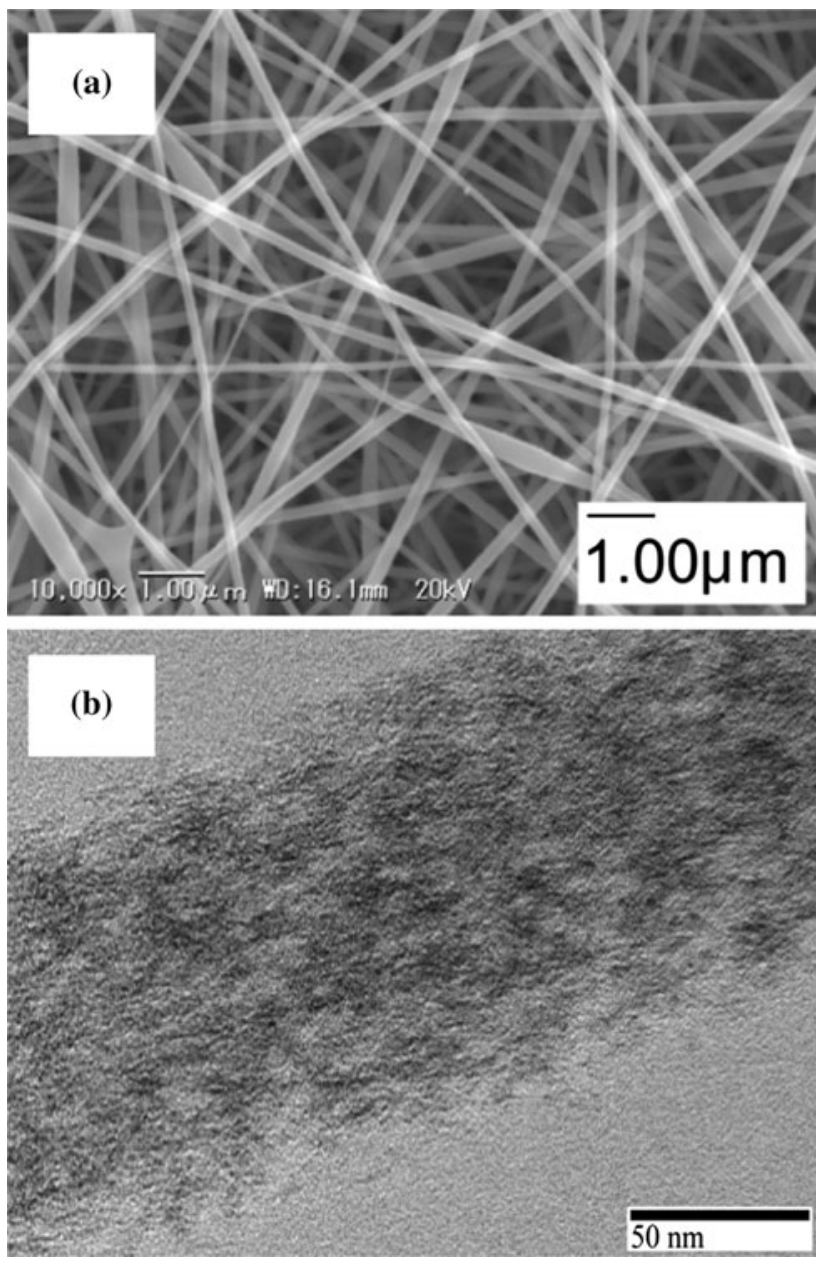

Fig. 1 a SEM and b TEM images of PVA/ $\mathrm{Nb}_{2} \mathrm{O}_{5}(70 / 30 \mathrm{wt} \%)$ composite nanofibers (precursors) obtained by ES

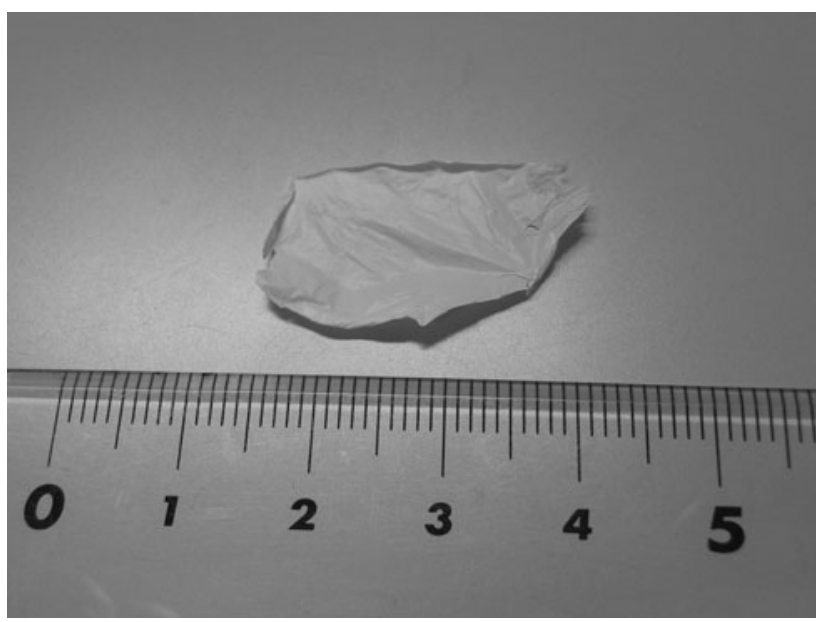

Fig. 2 A view of the precursor nanofiber mat heated at $500{ }^{\circ} \mathrm{C}$ 
$\mathrm{Nb}_{2} \mathrm{O}_{5}$ particles were dispersed homogeneously in the PVA matrix because a dark contrast was observed throughout the fiber.

White and brittle mats were obtained after heat-treatment of $\mathrm{PVA} / \mathrm{Nb}_{2} \mathrm{O}_{5}$ composite nanofiber mats at $500-1100{ }^{\circ} \mathrm{C}$ for $3 \mathrm{~h}$ in air. Figure 2 shows a view of the mat heated at $500{ }^{\circ} \mathrm{C}$. Figures 3 and 4 show SEM images and XRD curves of the $\mathrm{Nb}_{2} \mathrm{O}_{5}$ obtained. In Fig. 3, the $\mathrm{Nb}_{2} \mathrm{O}_{5}$ nanofibers were obtained below $700{ }^{\circ} \mathrm{C}$. But it changes shape from nanofiber to granular component above
$800{ }^{\circ} \mathrm{C}$. The average diameters of the nanofibers heated at 500,600 , and $700{ }^{\circ} \mathrm{C}$ were 102,89 , and $101 \mathrm{~nm}$, respectively. It is likely that the diameter did not depend on the heating temperature. These values are lower than that of the diameter of the precursor nanofiber $(170 \mathrm{~nm})$ because of the shrinkage of the fibers due to the thermal decomposition of PVA. In Fig. 4, the hexagonal $\mathrm{Nb}_{2} \mathrm{O}_{5}$ is formed at $500-600{ }^{\circ} \mathrm{C}$. Moreover, the orthorhombic and the monoclinic $\mathrm{Nb}_{2} \mathrm{O}_{5}$ are formed at $700-800{ }^{\circ} \mathrm{C}$ and 900-1100 ${ }^{\circ} \mathrm{C}$, respectively. Thus, the morphology change
Fig. 3 SEM images of $\mathrm{Nb}_{2} \mathrm{O}_{5}$ obtained after heat-treatment of $\mathrm{PVA} / \mathrm{Nb}_{2} \mathrm{O}_{5}$ composite nanofibers at $500-1100{ }^{\circ} \mathrm{C}$ for $3 \mathrm{~h}$ in air
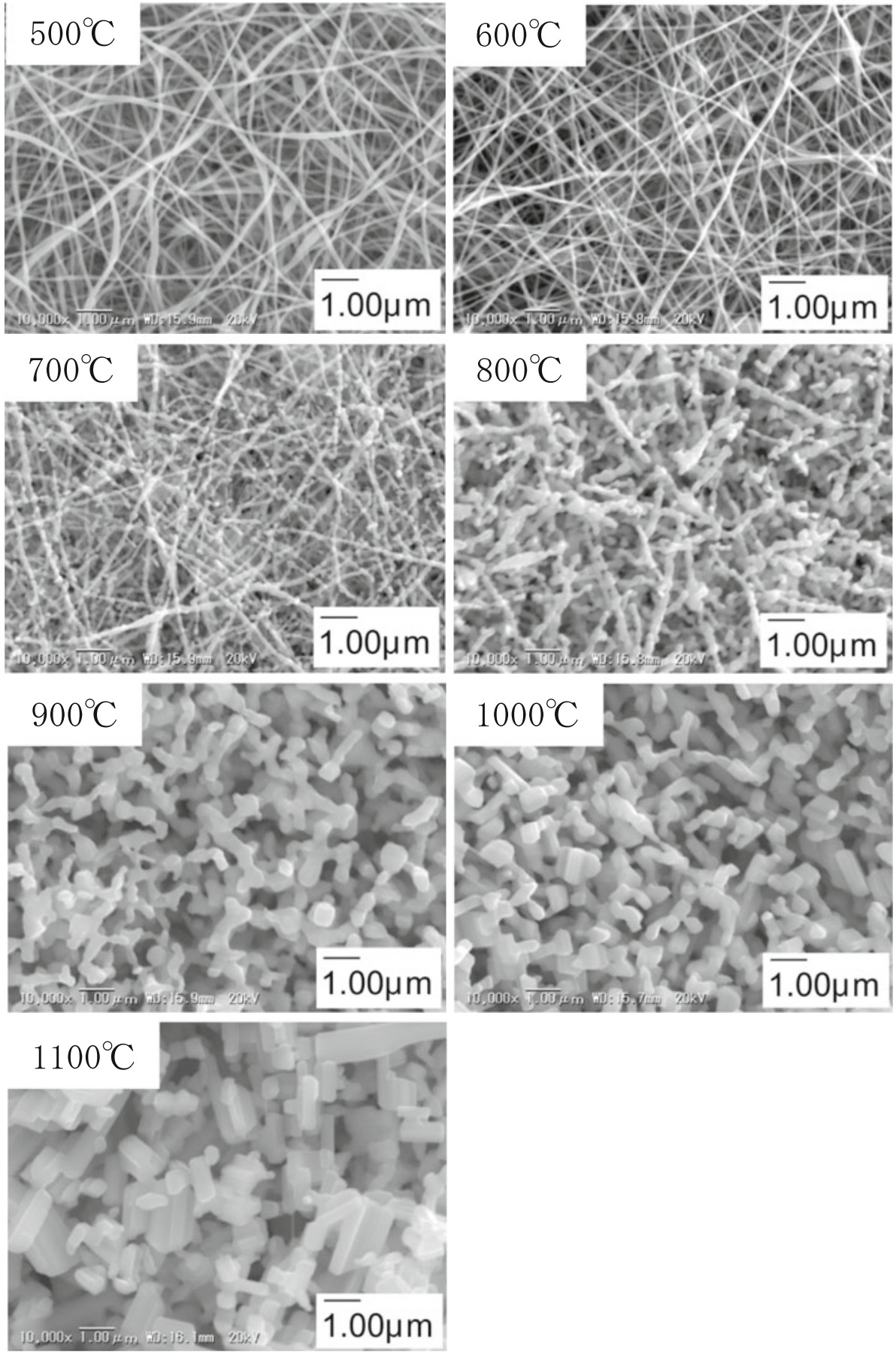


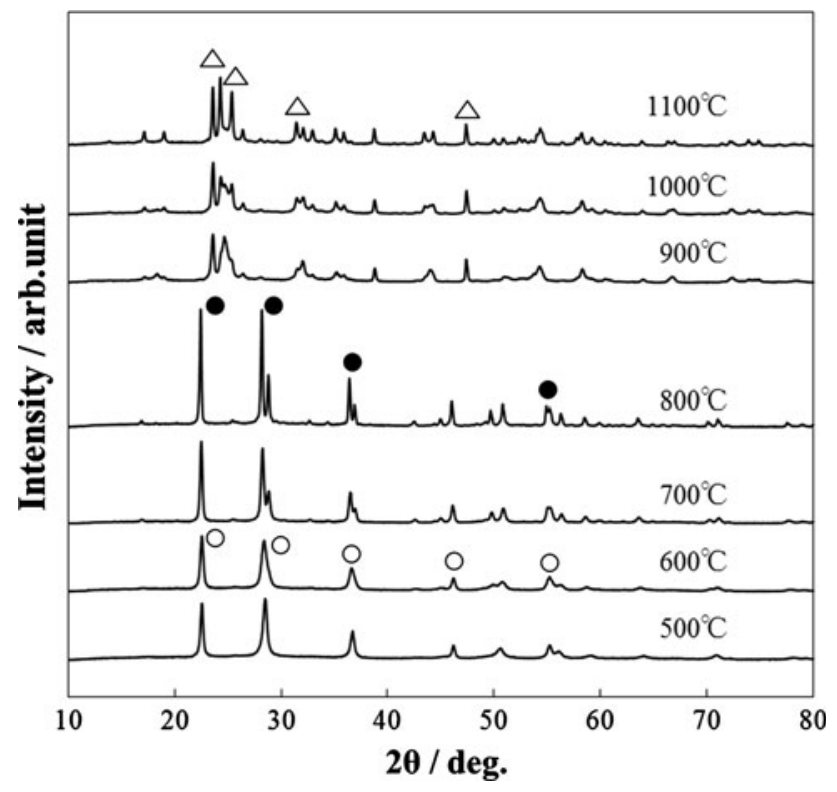

Fig. 4 XRD curves of $\mathrm{Nb}_{2} \mathrm{O}_{5}$ obtained after heat-treatment of PVA/ $\mathrm{Nb}_{2} \mathrm{O}_{5}$ composite nanofibers at $500-1100{ }^{\circ} \mathrm{C}$ for $3 \mathrm{~h}$ in air (open circle hexagonal $\mathrm{Nb}_{2} \mathrm{O}_{5}$, filled circle orthorhombic $\mathrm{Nb}_{2} \mathrm{O}_{5}$, open triangle monoclinic $\mathrm{Nb}_{2} \mathrm{O}_{5}$ )

of $\mathrm{Nb}_{2} \mathrm{O}_{5}$ in Fig. 3 would be caused by the crystal structure transformation from hexagonal-type (and orthorhombictype) to monoclinic-type.

The specific surface area and the pore volume of the $\mathrm{Nb}_{2} \mathrm{O}_{5}$ nanofiber heated at $500{ }^{\circ} \mathrm{C}$ for $3 \mathrm{~h}$ were $26.8 \mathrm{~m}^{2} / \mathrm{g}$ and $0.0507 \mathrm{~cm}^{3} / \mathrm{g}$, respectively. Considering the report of Zhou et al. [11], the highly porous $\mathrm{Nb}_{2} \mathrm{O}_{5}$ nanofibers could be obtained in this study due to the thermal decomposition of PVA in the precursors. Each value gradually decreased with increasing heating time due to the sintering; for example, the values were $15.5 \mathrm{~m}^{2} / \mathrm{g}$ and $0.0324 \mathrm{~cm}^{3} / \mathrm{g}$ after heat treatment at $500{ }^{\circ} \mathrm{C}$ for $24 \mathrm{~h}$. On the other hand, the porosity of the nanofibers rapidly decreased with increasing heating temperature. The specific surface area and the pore volume of the $\mathrm{Nb}_{2} \mathrm{O}_{5}$ nanofibers heated at $800{ }^{\circ} \mathrm{C}$ for $3 \mathrm{~h}$ were $3.94 \mathrm{~m}^{2} / \mathrm{g}$ and $0.0045 \mathrm{~cm}^{3} / \mathrm{g}$, respectively, and it is likely that the nanofibers became nonporous material.

Formation of $\mathrm{NbC}$ nanofibers by heat-treatment of precursors

The precursor nanofibers were heated at $800-1500{ }^{\circ} \mathrm{C}$ in Ar gas flow for $3 \mathrm{~h}$. Figure 5 shows the SEM images of the residues after the heat-treatment at various temperatures in Ar. The nanofibers were retained after each heating temperature. Figure 6 shows the effect of heating temperature on the average fiber diameter of the nanofibers obtained by the heat-treatment in Ar. The diameters of the resultant nanofibers decrease with increasing heating temperature up to $1100{ }^{\circ} \mathrm{C}$, and then they keep constant $(\sim 110 \mathrm{~nm})$ up to $1500{ }^{\circ} \mathrm{C}$

Figure 7 shows the XRD curves of the nanofibers after the heat-treatment in Ar gas flow. In Fig. 7, the peaks of $\mathrm{NbC}$ are observed from 800 to $1000{ }^{\circ} \mathrm{C}$, but other peaks such as $\mathrm{Nb}_{2} \mathrm{O}_{5}$ and $\mathrm{NbO}_{2}$ are also observed in the curves. Oxygen and carbon would be supplied from thermal decomposition of PVA. The peaks of $\mathrm{NbC}$ became sharp with increasing heating temperature, and the peaks of niobium oxide disappeared at $1100{ }^{\circ} \mathrm{C}$. Thus, we confirmed that $\mathrm{NbC}$ nanofibers could be formed above $1100{ }^{\circ} \mathrm{C}$.

The carbonization will typically proceed as follows $[17,18]$ :

$\mathrm{Nb}_{2} \mathrm{O}_{5}+7 \mathrm{C} \rightarrow 2 \mathrm{NbC}+5 \mathrm{CO}$

The Gibbs free energy change, $\Delta G^{\circ}$, for the reaction was given using the available thermodynamic data [19]. If the $\Delta G^{\circ}<0$, the reaction will proceed. The initial carbonization $(\mathrm{NbC})$ temperature calculated from thermodynamics data is $1229^{\circ} \mathrm{C}$. This temperature is higher than observed temperature, $1100{ }^{\circ} \mathrm{C}$ (as shown in Fig. 7), indicating that the precursor is a nano-scale mixture of $\mathrm{Nb}$ and carbon sources, and thus the reaction formula (1) would proceed effectively, or another reaction route might be created. 
Fig. 5 SEM images of residues after heat-treatment of PVA/ $\mathrm{Nb}_{2} \mathrm{O}_{5}$ composite nanofibers at $800-1500{ }^{\circ} \mathrm{C}$ for $3 \mathrm{~h}$ in $\mathrm{Ar}$
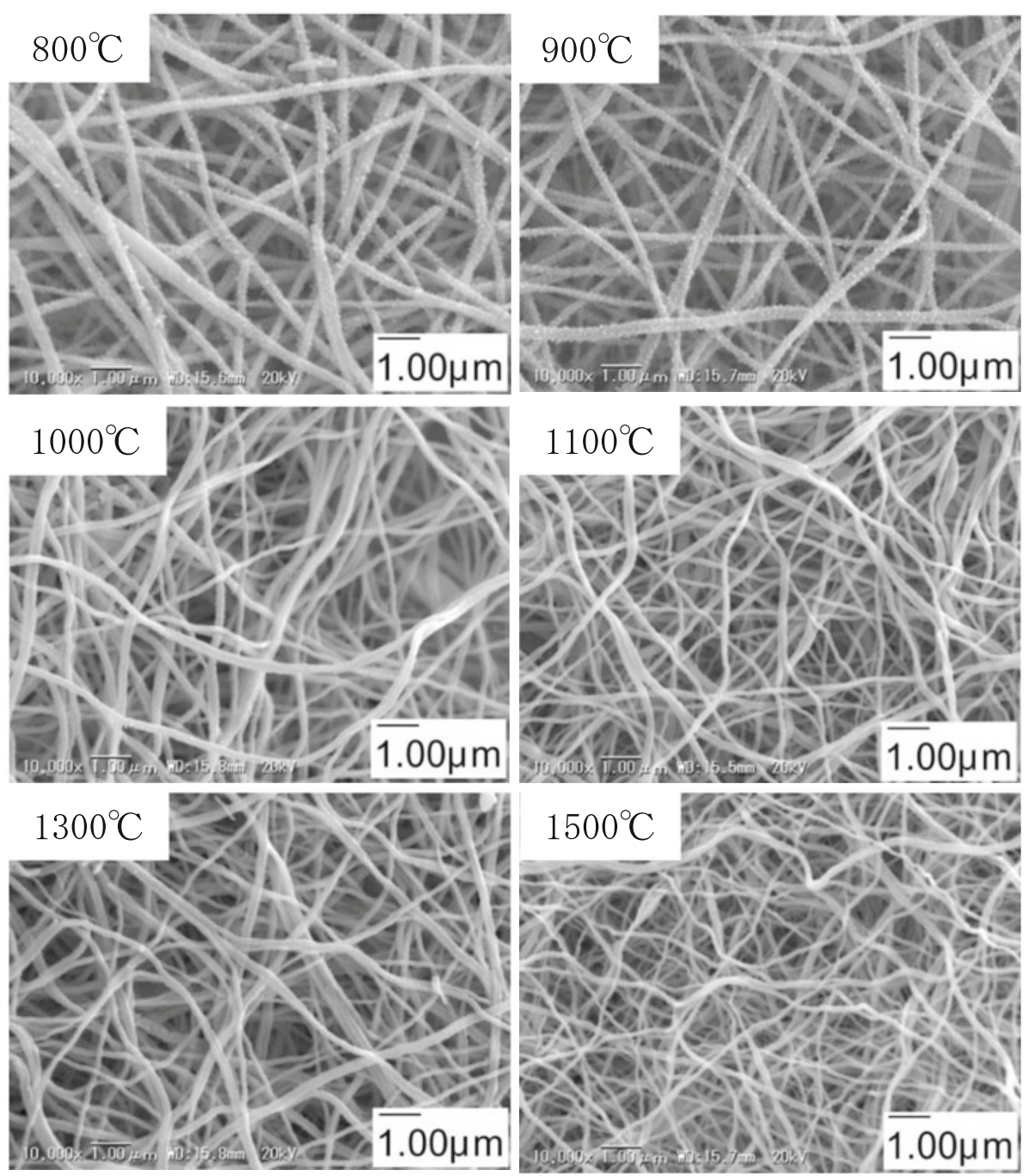

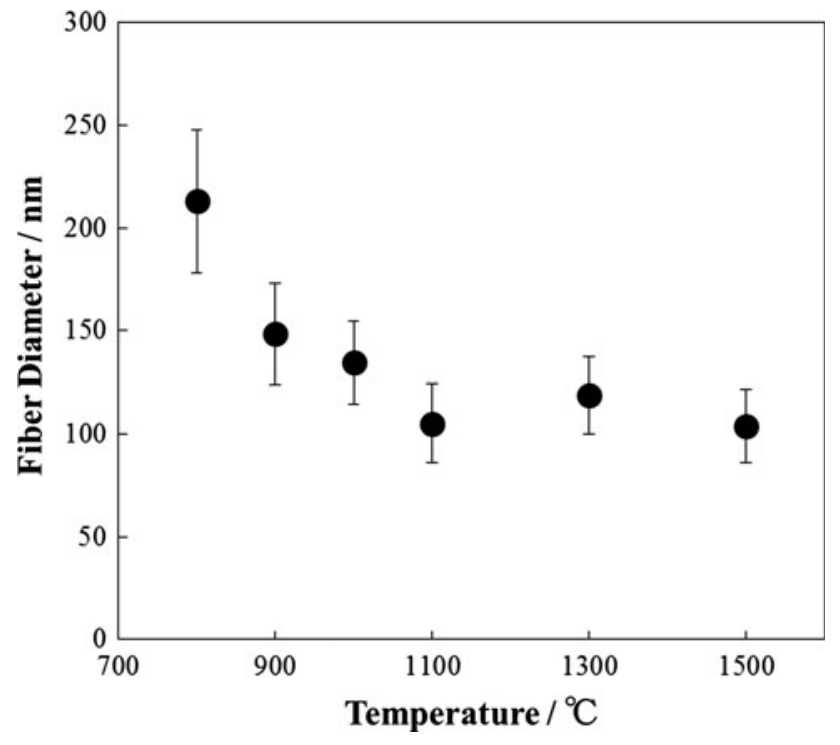

Fig. 6 Effect of heating temperature of the precursors on the average fiber diameter of the nanofibers obtained by heat-treatment of PVA/ $\mathrm{Nb}_{2} \mathrm{O}_{5}$ composite nanofibers in $\mathrm{Ar}$

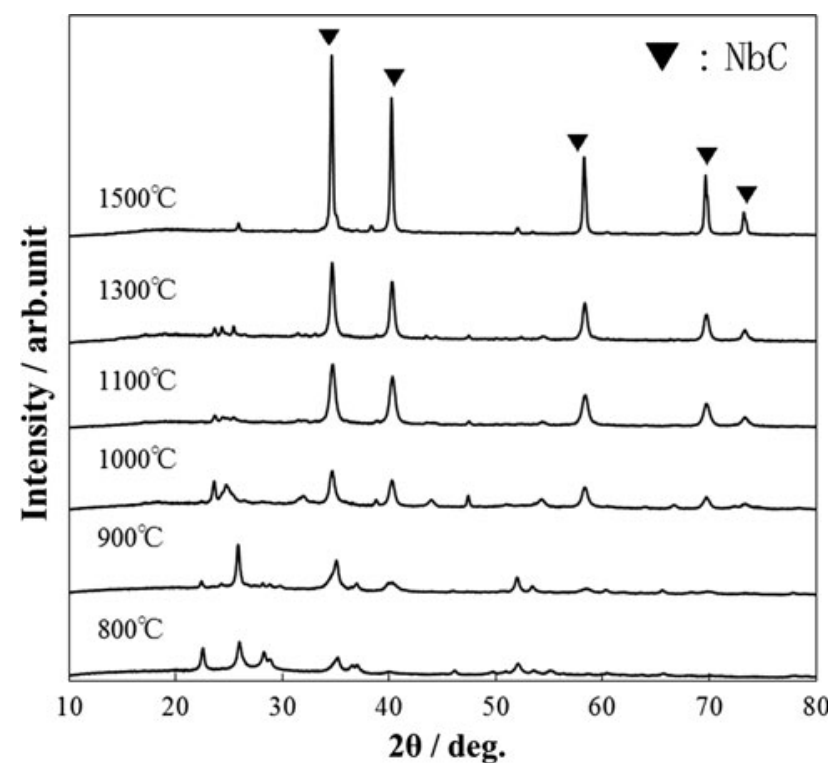

Fig. $7 \mathrm{XRD}$ curves of the nanofibers after the heat-treatment of $\mathrm{PVA} / \mathrm{Nb}_{2} \mathrm{O}_{5}$ composite nanofibers at $800-1500{ }^{\circ} \mathrm{C}$ for $3 \mathrm{~h}$ in $\mathrm{Ar}$ 


\section{Conclusions}

$\mathrm{PVA} / \mathrm{Nb}_{2} \mathrm{O}_{5}$ composite precursor nanofibers were formed by ES using PVA/ $\mathrm{Nb}_{2} \mathrm{O}_{5}$ nanoparticles aqueous solution as a spinning solution. Hexagonal $\mathrm{Nb}_{2} \mathrm{O}_{5}$ nanofibers were easily obtained by heat-treatment of the precursors in air. The nanofibers obtained were highly porous materials. $\mathrm{NbC}$ nanofibers could be formed at low temperatures by heating the precursors under Ar gas flow. Highly pure and highly crystalline $\mathrm{NbC}$ nanofibers will be formed by optimizing the heating conditions of the precursors in the next step.

Open Access This article is distributed under the terms of the Creative Commons Attribution License which permits any use, distribution, and reproduction in any medium, provided the original author(s) and the source are credited.

\section{References}

1. Chronakis IS (2005) J Mater Proc Tech 167:283

2. Ramakrishna S, Fujihara K, Teo WE, Lim TC, Ma Z (2005) An introduction to electrospinning and nanofibers. World Scientific Publishing Co. Pte. Ltd., Singapore, p 22

3. Li D, Xia Y (2003) Nano Lett 3:555

4. Guan H, Shao C, Liu Y, Yu N, Yang X (2004) Solid State Commun 131:107
5. Krissanasaeranee M, Vongsetskul T, Rangkupan R, Supaphol P, Wongkasemjit S (2008) J Am Ceram Soc 91:2830

6. Nakane K, Seto M, Irie S, Ogihara T, Ogata N (2011) J Appl Polym Sci 121:1774

7. Cui XM, Nam YS, Lee JY, Park WH (2008) Mater Lett 62:1961

8. Nam YS, Cui XM, Jeong L, Lee JY, Park WH (2009) Thin Solid Films 517:6531

9. Chen LJ, Liao JD, Lin SJ, Chuang YJ, Fu YS (2009) Polymer 50:3516

10. Nakane K, Nakanishi K, Kim JH, Yonezawa S, Ogihara T, Ogata N (2011) Sen'i Gakkaishi 67:261

11. Zhou Y, Qiu Z, Lu M, Zhang A, Ma Q (2008) Mater Res Bull 43:1363

12. Viswanathamurthi P, Bhattarai N, Kim HY, Lee DR (2003) Chem Phys Lett 374:79

13. Macias M, Chacko A, Ferraris JP, Balkus KJ Jr (2005) Microporous Mesoporous Mater 86:1

14. Viet AL, Reddy MV, Jose R, Chowdari BVR, Ramakrishna S (2010) J Phys Chem C 114:664

15. Pierson HO (1996) Handbook of refractory carbides and nitrides. Noyes Publications, New Jersey

16. Du J, Yang Y, Fan Z, Xia Y, Cheng X, Gan Y, Hang H, Dong L, Li X, Zhang W, Tao X (2013) J Alloys Compd 560:142

17. Oyama ST (ed) (1996) The chemistry of transition metal carbides and nitrides. Blackie Academic \& Professional, London

18. Kurokawa Y, Kobayashi S, Suzuki M, Shimazaki M, Takahashi M (1998) J Mater Res 13:760

19. Barin I (1993) Thermochemical data of pure substances. VCH, Weinheim 